\title{
Jurnal
}

Manajomen Polayanan Publik

Administration Of E-Invoicing Value Added Tax (Comparative Study between Indonesia and Australia)

Supply Chain Integration (SCI) Fashion Products Made By SMEs In Response To Improve Performance Development Of Tourism In West Java

Analysis on Fees Exemption Policy of Land and Building Rights Acquisition in Jakarta

Analysis of Tax Authority Readiness in Tax Policy on Digital Economy

Implementation of Large Scale Social Restrictions Policy (PSBB) in Bogor District Government

Critical Success Factors In Implementing Employee Information System Based On E-Government In The Bureau Of Public Affairs At The Regional Secretariat Of West Java Province

Implementation of Billboard Tax Policy in the City of Bandung

Public-Private Partnership In Water Supply Of DKI Jakarta 


\section{Analysis on Fees Exemption Policy of Land and Building Rights Acquisition in Jakarta}

Sonya Whisty Yogyandarua , Ima Mayasari ${ }^{b}$

a b Faculty of Administrative Sciences, University of Indonesia

\begin{abstract}
ABSTRAK
Kebijakan pengenaan 0\% (nol persen) Bea Perolehan Hak Atas Tanah Dan Bangunan di Provindi DKI Jakarta berdasarkan Peraturan Gubernur Nomor 126 Tahun 2017 implementasinya sudah berlangsung selama kurun waktu 4 (empat) tahun. Dalam praktik pelaksanaannya ditemukan banyak kelebihan dan kelemahan dari penerapan kebijakan. Penelitian ini bertujuan untuk mendeskripsikan hasil evaluasi dari pelaksanaan penerapan kebijakan pengenaan nol persen $B P H T B$. Penelitian ini menggunakan metode kualitatif deskriptif yang memberikan penjelasan dan pemahaman fenomena yang terjadi atas pemberian insentif perpajakan. Hasil penelitian menunjukan manfaat dari kebijakan ini adalah untuk meringankan beban masyarakat golongan ekonomi menengah ke bawah untuk bisa memiliki rumah di DKI Jakarta serta untuk mendorong percepatan program sertifikasi tanah. Implikasi dari penerapan kebijakan adalah banyak wajib pajak yang melakukan penghindaran pajak dengan memanfaatkan celah dalam Peraturan Gubernur untuk mendapatkan fasilitas perpajakan ini.
\end{abstract}

Kata Kunci : Analisis Kebijakan; Insentif Pajak; Bea Perolehan Hak Atas Tanah Dan Bangunan

\section{ABSTRACT}

The policy for imposing 0\% (zero-percent) Land and Building Title Acquisition Fee in DKI Jakarta Province under Governor Regulation Number 126 of 2017 has been implemented for a period of 4 (four) years. In practice there have been found various advantages and weaknesses in the course of policy implementation. This study aims to describe the result of the evaluation on the implementation of the policy imposing zero-percent of Tax Object Acquisition Value (BPHTB). This study used qualitative descriptive method which suggests the explanation and understanding of the phenomenon in the grant of tax incentive. The outcome from the study reveals that the benefit from the policy is the ease of tax burden for the lower middle class communities to own house in DKI Jakarta and to encourage the acceleration of the land certification. The policy implementation also however implies that many taxpayers avoid the tax by using loophole in the Governor Regulation to enjoy this tax facility.

Keywords: Policy Analysis; Tax incentive; Land and Building Title Acquisition Fee

\section{ARTICLE HISTORY}

Submited : 02/06/2020

Accepted : 18/06/2020

Published : $28 / 08 / 2020$

\section{KATA KUNCI}

Analisis Kebijakan; Insentif Pajak; Bea Perolehan Hak Atas Tanah Dan Bangunan

\section{KEYWORDS}

Policy Analysis; Tax incentive; Land and Building Title Acquisition Fee

\section{INTRODUCTION}

Law Number 33 of 2004 on Fiscal Balance between Central and Local Government, mandates the Local Governments to regulate their own internal affairs through by fiscal decentralization mechanism. Law Number $\mathbf{2 3}$ of 2014 on Local Government states that local regulation has its own source of funding from Local Revenue (PAD). Local Revenue consists of the revenue components, which is generated from local tax, local imposts, local enterprises and management of local assets after being separated from other legal components of tax, levies and revenue of other regions. 
The Special Capital Region of Jakarta Province (DKI) Jakarta is a Province with the highest Local Revenue in Indonesia as illustrated in the Local Revenue Realization Graph in each region of 2018 as follows:

Figure 1. Local Revenue Some Provinces Indonesia of 2018 (in trillion Rupiahs)

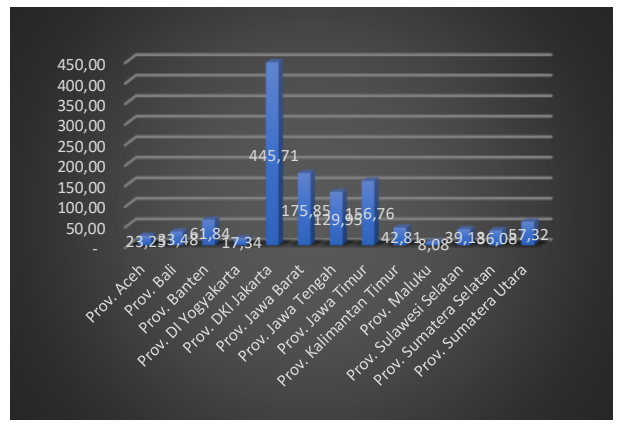

Source : Kemendagri.go.id (2018)

From the graph above, it is depicted that the Local Revenue Realization in DKI Jakarta Province is vastly significant if compared with the Local Revenue of other regions in Indonesia, therefore DKI Jakarta Province has major contribution in growth of national economy that may be regarded as the parameter of the national economic growth. The comparison in the said regions indicates that the gap between DKI Jakarta Province and other regions markedly far, with Province West Java ranked the Second in Local Revenue for instance the figures of Local Revenue at $153 \%$. This proved that DKI Jakarta must have the capacity to serve as the pilot project for the development of other regions in Indonesia.

Local Government Budget (APBD) of DKI Jakarta in 2018 showed the composition of tax revenue attained $87 \%$ (eighty seven percent) (Kemendagri, 2018). These data indicate that the more than fifty percent of the financing in DKI Jakarta is generated from the local tax revenue. Local tax revenue is one of the important elements and major contributor (most significant) in contributing to Local Revenue. Annually, the local tax revenue target in DKI Jakarta Province increased as shown in Figure 1.2 below:

Figure 2. Tax revenue realization in DKI Jakarta Province of 2015-2019 (in trillion Rupiahs)

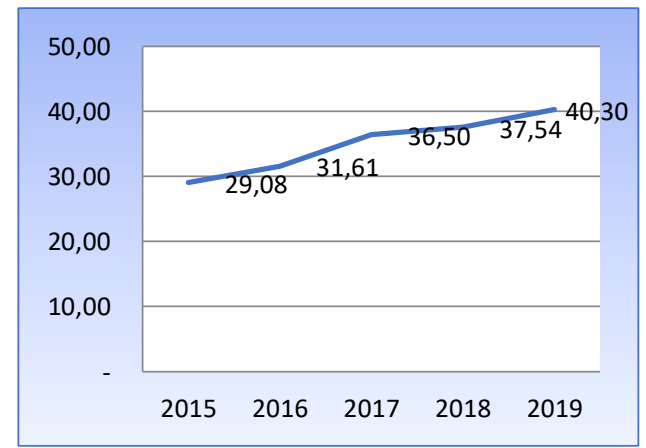

Source: Tax Performance Control and Guidance Department of Regional Taxation and Retribution Agency (BPRD) of DKI Jakarta Province (2019)

The figure above shows that the annual tax revenue target in DKI Jakarta Province significantly increased with average increase of $14 \%$ within the last 5 years. 
Law 28 of 2009 on Local Tax and Retribution mandated several types of taxes delegated to the local governments, at least there are 4 (four) new types of local taxes from the delegation of central government such as Acquisition Fee for Land and Building Title Acquisition (Tax Object Acquisition Value (BPHTB)), Rural and Urban Land and Building Tax (PBB P2), Cigarette Tax and tax Swallow Nest Tax. DKI Jakarta Provincial Government started managing the Tax Object Acquisition Value (BPHTB) per 1 January 2011 under Local Regulation Number 18 of 2010. This delegation of authority has generally increased local tax revenue in DKI Jakarta. The management of Tax Object Acquisition Value (BPHTB) is delegated from the Central government to the Local regulation effective as of 1st of January 2011.

The delegation of authority for fiscal decentralization in the collection of Tax Object Acquisition Value (BPHTB) from the Central government to the Local regulation will definitely have advantages and constraints. As mandated by Law Number 28 of 2009, DKI Jakarta Provincial Government has, from 2010, set up independent management from management system, Human resource, Local Regulation, facility and infrastructures. The system previously adopted by the Directorate General of Tax (DJP) in managing Tax Object Acquisition Value (BPHTB) is adopted by the Regional Taxation and Retribution Agency (BPRD), with improved system update data web-based which results in more accurate data update consistently.

The collection of Tax Object Acquisition Value (BPHTB) faced various constraints mostly in the Local Government. According to Suryanto (2018), the constraints are among others (1) various taxpayers incorrectly reporting the transaction price, (2) Local Government lacking of land market price database as the reference in calculating the Tax Object Acquisition Value (BPHTB), (3) The long validation process due to difficulties of the tax officer to find the actual proof of transaction, (4) There are still SSPD Tax Object Acquisition Value (BPHTB) validated but unpaid by the taxpayers, (5) Taxpayers lack of understanding on Tax Object Acquisition Value (BPHTB).

Since the early management of Tax Object Acquisition Value (BPHTB) in 2011, DKI Jakarta Provincial Government has targeted high revenue from Tax Object Acquisition Value (BPHTB) sector every year, as in the graph below:

Figure 3. Target Tax Object Acquisition Value (BPHTB) revenue (in trillion Rupiahs)

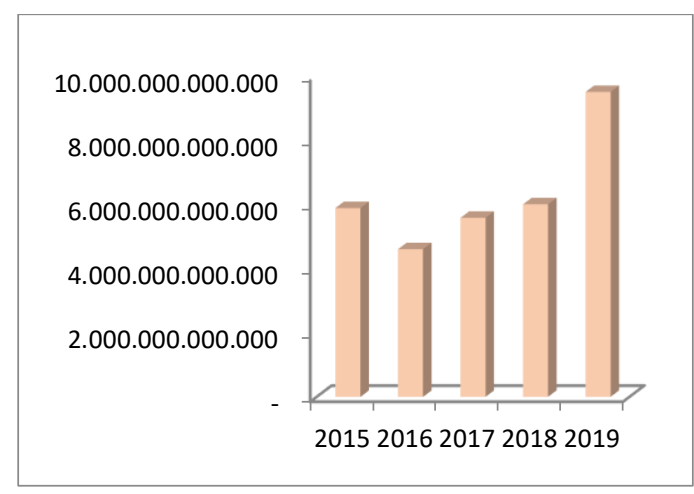

Source: Tax Performance Control and Guidance Department Regional Taxation and Retribution Agency (BPRD) DKI Jakarta Province (2019) 
As shown in Figure 3 above, the revenue from Tax Object Acquisition Value (BPHTB) in DKI Jakarta from 2015 until 2019 was highly fluctuating. This is aligned with that suggested by Donny Pamungkas (2018) that the amount of Tax Object Acquisition Value (BPHTB) revenue of DKI Jakarta fluctuated at all times, this is affected by the economic condition in the relevant region, also from other relevant factors. The highest Tax Object Acquisition Value (BPHTB) revenue as per data collected from DKI Jakarta Province Regional Taxation and Retribution Agency (BPRD) took place in 2019 with realized figures of IDR. 5.748.884.929.095, 00 or equal to 60,5\% of the target Tax Object Acquisition Value (BPHTB) in 2019.

The increase is the result of Tax Object Selling Value (Tax Object Selling Value (NJOP)) in DKI Jakarta Province which continued to increase every year after being managed under Local Regulation, since the Tax Object Selling Value (NJOP), as the tax base calculation for Tax Object Acquisition Value (BPHTB) did not increase for three years prior to delegation to the Local Government. The significant increase of Tax Object Selling Value (NJOP) has obviously influenced the market price of the Land and Building Sale which has also increased. Based on Article 5 Local Regulation (Local Regulation) DKI Jakarta Province Number 18 of 2011 on Land and Building Title Acquisition Fee, the tax base Tax Object Acquisition Value (BPHTB) is the Acquisition Value of Tax Object. In the course of sale, NPOP is the actual transaction value. Market price land continues to increase from year to year which result in difficulties to the lower middle class communities to have their land certification due to the burden to pay High Tax Object Acquisition Value (BPHTB).

On 13 October 2016, DKI Jakarta Provincial Government officially issued Governor Regulation (Governor Regulation) of DKI Jakarta Province Number 193 of 2016 on Exemption 100\% (one hundred percent) on Tax Object Acquisition Value (BPHTB) since the Sale or Grant of First New Title and/or Imposition of 0\% (zeropercent) Land and Building Title Acquisition Fee for Inheritance or Bequest with Tax Object Selling Value up to IDR. 2.000.000.000,00 (Two billion Rupiahs) rendered null and void by Governor Regulation (Governor Regulation) Number 126 of 2017 on Imposition of zero-percent on Tax Object Acquisition Value (BPHTB) on Acquisition of Firs New Title with Tax Object Acquisition Value up to 2 billion Rupiahs. DKI Jakarta Provincial Government has, per Governor Regulation No. 126 of 2017 granted tax incentive to the Jakarta societies in the exemption from Tax Object Acquisition Value (BPHTB).

This exemption from Tax Object Acquisition Value (BPHTB) policy is also one of the responses by DKI Jakarta Provincial Government to promote the package of economic policy volume III issued by the Ministry of Agrarian Affairs and Spatial Management. The extent of the package of this economic policy include among others, First, decreased electricity rate, price of oil fuel and gas. Second, the Extension of People Business Credit (KUR). Third, deregulation on investment for land permit by revising the Ministerial Regulation ATR/BPN Number 2 of 2015 on Service Standard and Agrarian Regulation, Spatial Management, and Land in Investment Activity.

This study used the 3 previous studies as the references and related to the Imposition Land and Building Title Acquisition Fee. First, the study conducted by Faulk (2006) suggested that the grant of property tax reduction in Indiana State own result positive related to the growth of the number of manufacture company and nonagricultural employment opportunity. Second, the study conducted by Rosentraub, et al. (2010) revealed that the policy for property tax reduction in Cleveland may re-generate the capacity of the Cleveland city in 
competing with other cities with the benefit from the policy to attract high-income communities to purchase houses in Cleveland. The benefits from this policy include increased public sector investment in Cleveland.

Third, the study by Febrian (2017) suggested that, in the context of policy implementation, the Tax Object Acquisition Value (BPHTB) exemption policy in DKI Jakarta Province took into account the political condition and incumbent government, including the fragmentation of the existing authorities. The Tax Object Acquisition Value (BPHTB) exemption policy in DKI Jakarta also played the role in supporting the acceleration of certification of land and Building Title in Jakarta. This study is different from the previous three studies since this study focused on analysis.

From the presentation of research background as above, the increase of Tax Object Selling Value (NJOP) in 2014 led to issues for soaring market price and causing difficulties of the communities to own houses in Jakarta. Another issue is the obligation to register the transfer of land and Building Title from the sale and purchase or bequest which posed additional burden for the Jakarta communities. In order to carry out the role of revenue distribution to create community welfare, then in response to the increased Tax Object Selling Value (NJOP), DKI Jakarta Provincial Government, as per Governor Regulation No. 126 of 2017, granted a fiscal stimulus in the form of zero-percent BPHTB imposition in response to such increased Tax Object Selling Value (NJOP). The purpose of this research is to explain the benefits and consequences in the course of implementation of Governor Regulation on BPHTB exemption No 126 of 2017. The implementation of zeropercent BPHTB imposition policy has been running for 3 years in DKI Jakarta, the researcher found it necessary to conduct a policy analysis to have an overview of success or failure from the zero-percent BPHTB imposition policy on the first title acquisition. It is expected that in the future an ideal policy design for BPHTB exemption can be realized.

\section{LITERATURE REVIEW}

\section{Study on Public Policy Theory}

Public policy is defined as any action adopted by the Government on what to be done or not and which regulate matters related to public welfare. Public policy should regulate behavior, organize bureaucracy, distribute resources, tax collection or all other aspects. Based on Dye (2013) concept, the three important correlative matters in the policy system consist of 3 (three) elements namely: public policy, policy maker and political environment which are correlated as integral part.

One of the important phases in the formulation of public policy is the agenda setting, a phase during which a problem is taken as the attention for the Government to be made into a policy (Kusumanegara, 2010). Agenda setting is defined as a demand so that the decision makers will adopt or be encouraged to take particular action (Winarno, 2007). The problem identification in the phase of agenda setting may help reveal the issues in the communities, explain the causes and set the purpose or model policy taken to resolve the problem.

\section{Policy Analysis Theory}

Dunn (2018) in his book title Introduction Public policy analysis suggested that there are 6 (six) primary types 
of criteria to recommend decision. The criteria of decision explicitly have the basic values required to have the best policy recommendation for problem solving. The six types of criteria are explained in the table below:

Figure 4. Policy Analysis Criteria

\begin{tabular}{|c|c|c|}
\hline CRITERIA TYPE & QUESTIONS & ILLUSTRATION \\
\hline Effectiveness & $\begin{array}{l}\text { What are the expected } \\
\text { outcomes? }\end{array}$ & Service Unit \\
\hline Efficiency & $\begin{array}{l}\text { How many efforts required to } \\
\text { accomplish the expected } \\
\text { outcomes? }\end{array}$ & $\begin{array}{l}\text { Cost Unit } \\
\text { Net Benefit } \\
\text { cost-benefit ratio }\end{array}$ \\
\hline Adequacy & $\begin{array}{l}\text { To what extent the achievement } \\
\text { of outcome expected for } \\
\text { problem solving? }\end{array}$ & $\begin{array}{l}\text { Fixed cost (problem type I) } \\
\text { Fixed effectiveness (problem } \\
\text { type 11) }\end{array}$ \\
\hline Even Distribution & $\begin{array}{l}\text { Whether the cost and benefit } \\
\text { evenly distributed to different } \\
\text { groups? }\end{array}$ & $\begin{array}{l}\text { Pareto Criteria } \\
\text { Kaldor- Hicks Criteria } \\
\text { Rawls Criteria }\end{array}$ \\
\hline Responsiveness & $\begin{array}{l}\text { Does the policy outcome satisfy } \\
\text { the need, preference or value of } \\
\text { certain groups? }\end{array}$ & Consistency with citizen survey \\
\hline Accuracy & $\begin{array}{l}\text { Is the outcome (objective) } \\
\text { useful or valuable? Public } \\
\text { program must be even and } \\
\text { efficient. }\end{array}$ & \\
\hline
\end{tabular}

Source: Introduction to Public policy analysis William Dunn (2018)

Dunn explains that formulation of public policy must correspond to the criteria of even distribution related to legal and social rationality referring to the distribution of consequences and efforts among different groups in the communities. A program or action in one policy may be effective, efficient and adequate yet generates uneven distribution of cost and benefit, and based on the criteria of even distribution, program will not be selected or the policy will not be implemented.

This used the theory of public policy analysis by Willian Dunn as the reference in analyzing the problem. Use of the policy analysis criteria, especially the criteria of even distribution will help discover the extent of benefit and consequences which may arise from a public policy and help the policy maker decide the kinds of programs to be resumed or terminated in the current public policy. Based on this, the theory of Public policy analysis by William Dunn is regarded as the most accurate in analyzing the implementation of BPHTB Exemption Policy in DKI Jakarta.

\section{Land and Building Title Acquisition Fee Theory}

The distribution of duties and authorities between the Central Government and Government is the consequence from the decentralization since part of the duty of the Central Government is delegated to the local government. The definition of central tax and local tax is not unlike in substance. According to Salomo (2002) local taxation and central taxation is an integrated system. Prichard (2015) in his journal "The Political Economy of Property Tax in Africa: Explaining Reform Outcomes in Sierra Leone' suggested the importance 
of local tax reform to achieve successful decentralization pivoted on the independency of Local government and response of the communities as the tax payers.

Title Transfer means Transfer of Title held after the other party releases its right. There are two theories in the Title transfer in the law science, abstract and casual theory. The abstract theory explains that the legalization of levering regardless the illegality of the obligator, however the levering process is valid. While casual theory suggests levering as dependent on the legality or illegality of the obligator agreement (Suparmoko, 2006).

\section{Taxation Incentive}

Taxation Incentive is a facility provided by the Government in taxation sector. One of the purposes of this incentive is to counterbalance the deficiency that the communities may face various constraints, such as lack of infrastructures, complicated bureaucracy, weak administration and burdening tax imposition (Nurul.et al, 2016). The solution in incentive is sometimes hindered in the implementation however tax incentive may offer temporary solution. Holland and Vann as excerpted by Thuronyi in the tax law design and drafting (1996) ch.23, page. 4 classified tax incentive into Tax Holiday, Investment Allowances and Tax Credit, Timing Differences, Reduced Tax Rates, Free Economic Zones.

\section{RESEARCH METHODS}

The research used qualitative method. Here, the general model includes the theoretical framework used, while the specific model was the reality found by the researcher in the field (Creswell, 2014). This research is used to acquire explanation and understanding of the phenomenon on the tax incentive policy in the form of zero-percent BPHTB imposition.

The collection technique used in this research is divided into two namely field study with in-depth interview and collecting and studying the data and information related to BPHTB. The source informants selected were the stakeholders with formulation of BPHTB Exemption Policy and technical policy operators from DKI Jakarta Province Local Revenue Agency as the tax collecting authorities in Jakarta, academicians and local taxpayers as the parties related to the application for BPHTB exemption.

The qualitative data analysis technique in this research was conducted in the following phases: first, data reduction by selecting, focusing and coding verbatim data through literature study, in-depth interview to the party directly related to the subject matter. Second, data presentation through presentation of data by correlating the category from the data source. Third, conclusion drawing upon finding of temporary conclusion and change to final conclusion supported by valid and consistent evidence.

The discussion on the issue in this research will focus on the policy analysis from the local tax incentive in the form of zero-percent BPHTB imposition policy with Tax Object Selling Value (NJOP) up to 2 billion Rupiahs in DKI Jakarta Province. 


\section{RESULTS AND DISCUSSIONS}

\section{Benefit from BPHTB Exemption Policy}

Tax incentive or facility is sweetener to attract more investors and generate the behavior business or business players. The facility actually offers ease provided by the Government. Hence, the object which has tax payable, with the facility given, has no tax payable whether in part or in whole. The facility may also be assumed as inconsistent with the tax concept, since this facility deviates from general conditions of tax which is the policy issued by the Government. However, the Government will usually have special consideration in the policy taking, such as the set target.

The procedure for the implementation of policy on BPHTB reduction and exemption in DKI Jakarta was initiated by the issuance of similar regulation in 2011 as per DKI Jakarta Governor Regulation Province Number 103 of 2011 on BPHTB Reduction, Allowance and exemption. One of the underlying basis for the issuance of the BPHTB Exemption Policy was Law Number 28 of 2009 on Local tax and Retribution which stipulated that effective as of 1 January 2011, BPHTB which was previously central government tax changed to local government tax. Based on this, there will be necessary the transitory and adaptation period in the collection procedure of BPHTB for the Local government especially DKI Jakarta Province to prepare technical or non-technical matters to collect BPHTB. (Falah, 2012).

Toward the end of 2016 exactly 13 October 2016 DKI Jakarta Provincial Government issued BPHTB exemption and zero-percent imposition Policy as per DKI Jakarta Governor Regulation Number 193 of 2016 on BPHTB exemption for Sale or First New Title with Tax Object Selling Value (NJOP) up to 2 billion Rupiahs. Unlike the previous regulation, Governor Regulation Number 193 of 2016 sets the purpose to promote the policy of the Central Government to support the investment deregulation policy in land sector to accelerate land and building certification especially in DKI Jakarta Province and to promote investment in property sector.

DKI Jakarta Governor Regulation Number 193 of 2016 was revised by DKI Jakarta Governor Regulation Number 126 of 2017 on 0\% (zero-percent) imposition on BPHTB for First Title Acquisition with Tax Object Selling Value (NJOP) up to 2 billion Rupiahs issued on 13 September 2017 upon which, DKI Jakarta Governor Regulation Number 193 of 2016 was declared null and void.

BPHTB exemption facility set forth in the Governor Regulation Number 126 of 2017 is granted only to Individual Taxpayer meeting requirements, this is with a view to provide legal assurance for the taxpayers legally entitled to enjoy the BPHTB exemption facility. There are 2 (two) primary goals related to the issuance of the Governor Regulation. First, to ease the burden of low-income communities to own their houses in Jakarta City. Article 3 of the Governor Regulation stipulates the scope of imposition 0\% BPHTB set forth in the Governor Regulation Number 126 of 2017 for BPHTB payable on First Title Acquisition including Transfer of Title and New Title with Tax Object Selling Value (NJOP) up to 2 billion rupiahs. Below is the calculation of BPHTB payable to the taxpayers first acquiring land and Building Title transfer through sale transaction with Tax Object Selling Value (NJOP) below 2 billion rupiahs prior to and after the zero-percent BPHTB imposition policy: 
Table 1. Calculation Pre and Post Policy BPHTB Payable

\begin{tabular}{|l|l|l|}
\hline & Pre Policy & Post Policy \\
\hline NPOP & Rp. 1.178.460.000 & Rp. 1.178.460.000 \\
\hline NJOPTKP & Rp. 80.000 .000 & Rp. 80.000 .000 \\
\hline DPP BPHTB & Rp. 1.098.460.000 & Rp. 1.098.460.000 \\
\hline BPHTB Payable & $\begin{array}{l}5 \% \times \text { Rp. } 1.098 .460 .000= \\
\text { Rp. } 54.923 .000\end{array}$ & $\begin{array}{l}\text { 0 (zero-percent BPHTB imposition policy } \\
\text { for Tax Object Selling Value (NJOP) } \\
\text { under 2 M) }\end{array}$ \\
\hline
\end{tabular}

Source: UP3D Jagakarsa Sub-District (Researcher-processed data, 2020)

In the above case, it was known that the monthly income of the taxpayer was IDR. 5.500.000,- in one year Bapak Sukirman earned total gross income of IDR. 66.000 .000 ,- which means which this income capacity of the taxpayer, he must spend IDR.54.923.000,- or $83 \%$ of the total annual income only to pay the BPHTB obligation. However, with BPHTB zero-percent imposition policy set forth in the Governor Regulation 126 of 2017, the taxpayer is not obliged to pay BPHTB.

Given the example above, the taxpayers earning monthly income of IDR.66.000.000,- must not spend more to pay BPHTB so that the purpose of the Governor Regulation 126 of 2017 to ease the burden of low-income communities to own their house may be realized.

Second, the purpose of BPHTB Exemption Policy set forth in the Governor Regulation Number 126 of 2017 is to encourage DKI Jakarta Residents to certify their land and/or building which was due to expensive cost of certificate formalities causing uncertificated land parcels in DKI Jakarta Province of 20,64\% of the total land parcels in DKI Jakarta Province (Central Statistic Bureau of DKI Provincial Government, 2019). Degree of change expected to occur in the implementation of Governor Regulation 126 of 2017 is the accelerated land certification in DKI Jakarta Province and therefore it is expected that the communities reluctant to certify their lands due to expensive formalities for land certificate will find this policy as the solution for these problem.

Based on data from the National Land Agency DKI Jakarta Regional Office it is found that until June 2019 the realization of land certification was registered at 135.436 land parcels certified. These figures reached $89,03 \%$ of all areas in DKI Jakarta Province not certificated or increased 9,54\% of the total land parcels certificated in 2018 at 79,49\%. Based on data from the National Land Agency DKI Jakarta Regional Office until 2019: 
Table 2. Realization of Land Parcels Registered by Administrative City in 2019

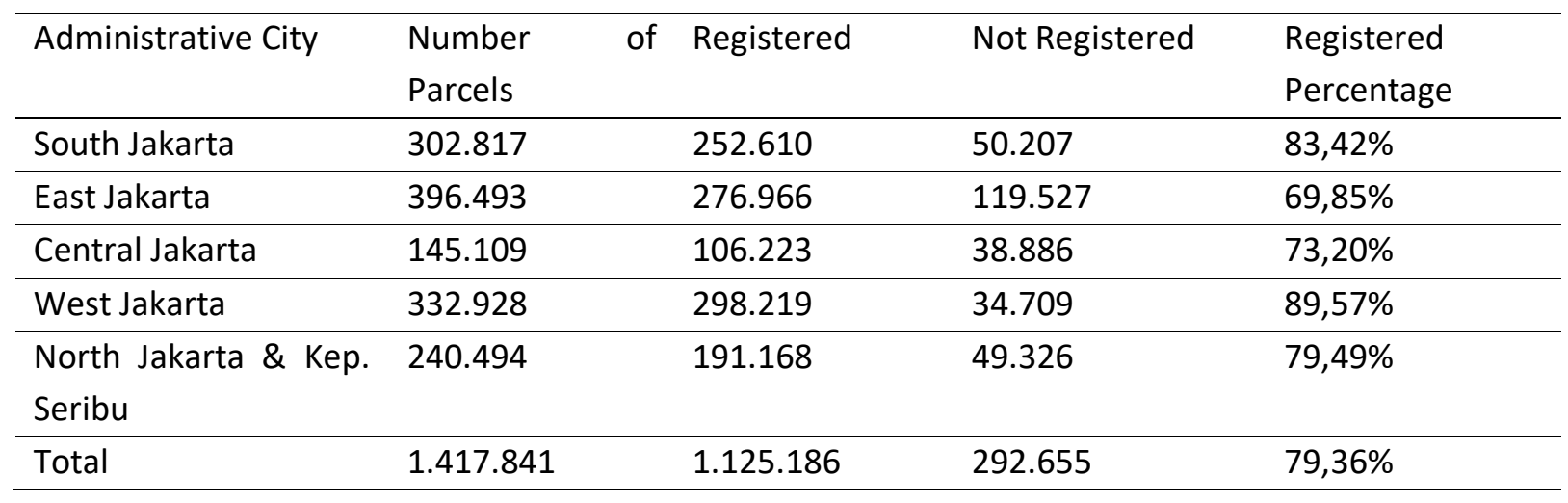

Source: National Land Agency Regional Office DKI Jakarta Province (Researcher-processed data, 2020)

The table 2 above shows that the realization of land legalization in DKI Jakarta Province until 2019 was $79,36 \%$ hence there are still 20,64\% uncertificated lands in DKI Jakarta. One of the purposes of the Governor Regulation 126 of 2017 was to accelerate land certification in DKI Jakarta Province therefore, it is necessary to analyze whether in 2019 there were increased issuance of certificate compared with the same period in the previous year. This can be analyzed in the graph below:

Figure 5. Realized Issuance of Land certificate in DKI Jakarta Province January to June 2018 and January to June 2019 Comparison

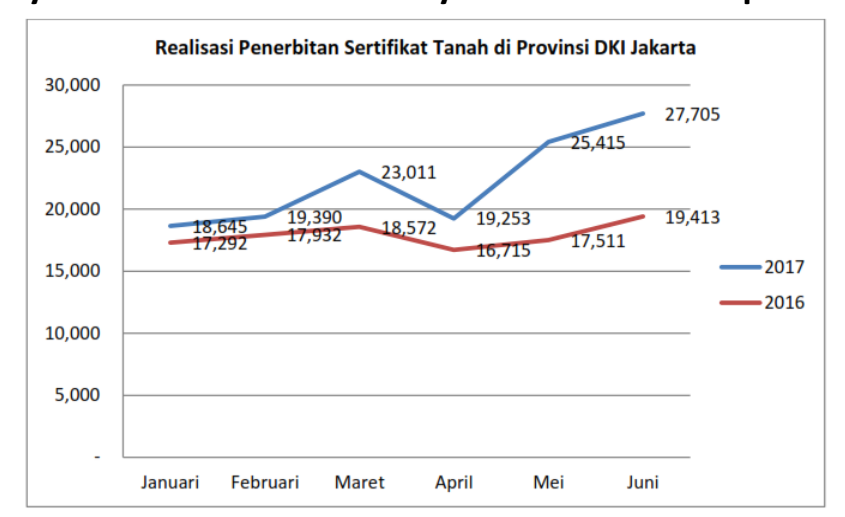

Source: National Land Agency Regional Office DKI Jakarta Province (Researcher processed data, 2020)

The figure above reveals that there was increased number of issuance of land certificate in DKI Jakarta Province of 135.436 certificates distributed from January to June 2019 compared with the same period from January to July 2018 for 109.451 certificates. This showed that the Governor Regulation Number 126 of 2017 to accelerate the land certification in DKI Jakarta has been fairly implemented. Out of the remaining 292.655 land parcels uncertificated in 2018 there were certificated 135.436 parcels, hence the overall target of land certification in DKI Jakarta Province until June 2019 reached 88,90\%. 


\section{Implication of BPHTB Exemption Policy}

The growth level of property sector in DKI Jakarta has rapidly increased. Asosiasi REI (Real Estate Indonesia) predicted that property business will continue to grow to reach 20-30 percent (Property Business Grow 30\%, 2014). Aligned with the rapid development in DKI Jakarta, the property market price will also increase. However, the significant increase of property market price has not been followed by on-going adjustment to Tax Object Selling Value (NJOP) which results in far gap between the market price and Tax Object Selling Value (NJOP). Adjustment to the Tax Object Selling Value (NJOP) DKI Jakarta was first made in 2014 after the last 3 (three) years, the Tax Object Selling Value (NJOP) in DKI Jakarta has not been adjusted. Below are some examples of comparison of Tax Object Selling Value (NJOP) Land and Building Tax for protocol road prior to and after the adjustment.

Table 3. Comparison of Tax Object Selling Value (NJOP) Land and Building Tax 2013 and 2014 (price per square meters in millions rupiahs)

\begin{tabular}{|c|c|c|c|}
\hline Location & 2013 & 2014 & Increase \\
\hline Jl. Mh Thamrin & 33.445 .000 & 68.545 .000 & $105 \%$ \\
\hline Jl. Jend. Sudirman & 31.875 .000 & 66.255 .000 & $108 \%$ \\
\hline Jl. Gatot Subroto & 28.855 .000 & 59.625 .000 & $107 \%$ \\
\hline Jl. Rasuna Said & 27.405 .000 & 41.895 .000 & $53 \%$ \\
\hline
\end{tabular}

Source: DKI Jakarta Local Revenue Agency (Researcher-processed data, 2020)

The total average of increase of Tax Object Selling Value (NJOP) in DKI Jakarta areas reached 82,2\%. Adjustment to the Tax Object Selling Value (NJOP) has increased the revenue for DKI Jakarta from local tax, realized revenue from local tax in 2014 reached 5,7 trillion increasing $67 \%$ of the previous year amounting to 3,4 trillion. However, the significant increase of Tax Object Selling Value (NJOP) posed impact on the communities which has resulted in greater amount of BPHTB payable, which directly affects the communities.

The policy taken by the Government will be conducted through series of phases established by Law. It starts from formulation through ruling and implementation thereof. The formulation of public policy is one of the phases from the series of public policy making and implementation. The researcher is of the opinion that the model used in the formulation of DKI Jakarta Governor Regulation Province Number 126 of 2017 is a rational model. Rational model is defined as a model where decision making procedure which guides the selection of alternatives will be from the most efficient from the achievement of the policy objectives. The problems are solved through scientific or rational method, e.g. by collecting all information related to the problem and alternative solution, and selecting the best alternative.

The formulation process of DKI Jakarta Governor Regulation Number 126 of 2017 is swift which was the intention of DKI Jakarta Governor to help low-income communities and to promote land certification in DKI 
Jakarta by fixing Tax Object Selling Value (NJOP) up to 2 billion as the indicators for community group eligible to zero-percent BPHTB imposition facility. The formulation of policy adopted rational formulation model since some matters caused limited human rationality which was not error free (Banuaji, 2016) First, human has intellectual limitation. Second, human has limited information caused by abundance or lack of information gained. Third, human has always been encountered by conflicts of values and interest of communities. Fourth, human has limited time, energy and cost. The implementation of Governor Regulation 126 of 2017 on 0\% (zero-percent) BPHTB imposition in DKI Jakarta has some weaknesses, as foreseen in the formulation process or impact after the regulation came into force.

In relation to the figures 2 billion in the zero-percent BPHTB imposition policy, there have been arising many questions from the investors and communities why the figures 2 billion were fixed as the limit of Tax Object Selling Value (NJOP) exempted from BPHTB. Local Tax and Retribution Agency together with the relevant authorities decided with some justifications. The figure 2 billion as the limit for Tax Object Selling Value (NJOP) with zero-percent BPHTB imposition facility is considered as reasonable also by measuring the capacity of the lower middle class communities to make use of them that the purpose of the policy can be realized (Ortax, 2017). The calculation of BPHTB payable in the amount of 5 percent multiplied by the value of assets is very costly for lower middle class of communities. If the value of the land owned worth IDR 1 billion, the BPHTB to be incurred will be IDR 50 million as a minimum. That has been cause by many DKI Jakarta Residents complained about the expensive cost of land formalities, there were as if thugs, instead of expensive BPHTB (Tempo, 2016).

According to Nurmantu (2005) there are some general principles of local taxation to be implemented, one of them is which is politically acceptable to the communities to raise their individual motivation and awareness to pay tax. Tax or retribution must not cause excessive extra burden which may affect the communities (deadweight loss). The problem rose due to the significant increase of Tax Object Selling Value (NJOP) and the communities must pay costly BPHTB.

Communities as the taxpayer demand at all times small amount of tax. Efforts by the Government in collecting tax are still shadowed by the tax avoidance practices. Tax avoidance is a mean to ease the tax burden without violating the law (Mardiasmo, 2011). Tax avoidance occurs by some factors, one of the factors likely giving rise to tax avoidance rests with the rules, the regulation contains Loophole to avoid tax. Potential tax avoidance in the $0 \%$ (zero-percent) BPHTB imposition policy mostly used by the taxpayers is the acknowledgement of transaction value in the transaction. Local Regulation of DKI Jakarta Province Number 18 of 2010 on BPHTB article 5 states that the basis for BPHTB imposition is the acquisition value of Tax Object (NPOP). Article 5 paragraph (2) Local Regulation states that the sale transaction of NPOP is the transaction value. Article 5 paragraph (3) explains that if the NPOP referred to in paragraph (2) is unknown or lower than the Tax Object Selling Value (NJOP) of Land and Building Tax, the basis for calculation of BPHTB payable is the Tax Object Selling Value (NJOP) of Land and Building Tax.

The loophole in the article 5 Local Regulation BPHTB has often been used by the taxpayers in calculating the amount of BPHTB payable by reporting false value of sale transaction. Many taxpayers reporting the validation of BPHTB by understating the value of sale transaction which results in lesser amount of BPHTB 
payable. This also occurs in the use of zero-percent BPHTB imposition policy, where many tax-payer submitted application for BPHTB allowance with non-actual transaction value, they reported the value below 2 billion rupiahs to enjoy the zero-percent BPHTB imposition. This false reporting by the taxpayer of the amount of BPHTB paid showed that taxpayer compliance with BPHTB is low due to the loopholes in the present regulation on BPHTB.

As defined by Koeswara, the compliance shows the strength which explicitly influences the individual and typical response by individuals to others with higher status power. The compliance level of the taxpayer with taxation law referred to as tax compliance (Koeswara, 1995). In the said definition, it appears that the overall compliance of taxpayers with the tax regulation, which includes the compliance with income reporting, filling Annual Return and payment of tax payable. There are many cases where taxpayers reporting the validation of BPHTB not using the real transaction value indicates low compliance level of taxpayers.

The threshold set in the amount of 2 billion appears to be as less relevant option when the purpose of the policy is to promote the opportunity of the lower middle class communities to own their houses due to uneven use in DKI Jakarta Province since the acquisition value of Tax Object (NPOP) in DKI Jakarta Province is high compared with other provinces within the territory of the Republic of Indonesia. This is proven by the data of online property sale website, Trovit on Primary Property Price Index as follows:

Figure 6. Average Property Price for House Category in DKI Jakarta Province Year 2019

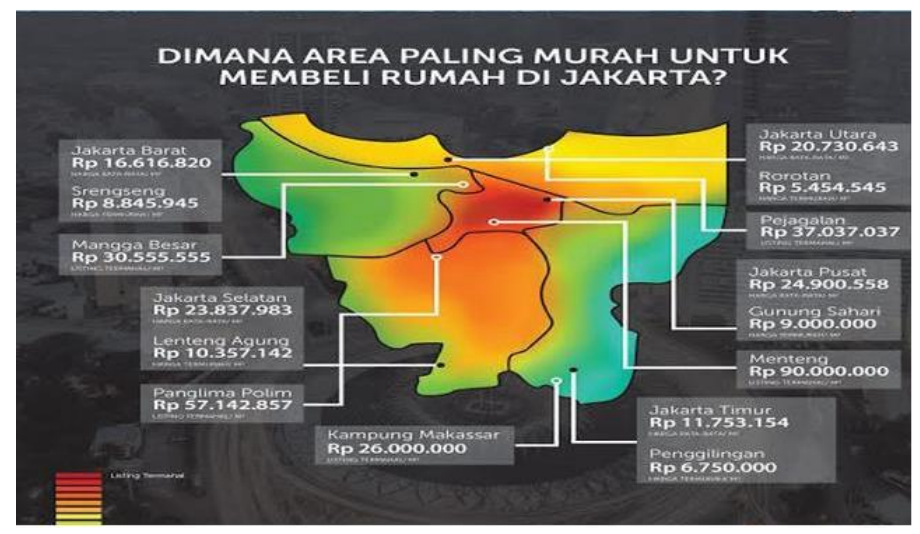

Source : Rumah Bandung Trovit (2019)

The above figure shows that the average property price for house category in DKI Jakarta Province in 2019 ranged at the average of IDR. IDR. 16.808.534,- /square meter, hence to own a residential houses of 100 square meters DKI Jakarta Residents must spend about IDR. 1.680.853.400,- per unit. If DKI Jakarta Provincial Government targets the lower middle class communities in this policy, it appears less accurate if the figures 2 billion be fixed as the threshold for Tax Object Selling Value (NJOP) with zero-percent imposition, since based on the data of increase average Property price for residential house and apartment category which continue increase has caused the scope of DKI Jakarta area as the target for the communities to use this facility to be narrower with less Tax Object Selling Value (NJOP) in DKI Jakarta below 2 billion. It is necessary for DKI Jakarta Provincial Government to review the Taxation Incentive strategy through zero-percent BPHTB imposition policy with 2 billion limits as the reference for BPHTB exemption in DKI Jakarta Province in the 
Governor Regulation Number 126 of 2017, basically the Tax Object Selling Value (NJOP) in DKI Jakarta Province continues to increase. Not all segments of communities may enjoy the facility if the objective of the policy is to provide ease for all DKI Jakarta Residents to own houses.

\section{CONCLUSIONS}

Based on the above, it may be concluded that the benefits from the implementation of $0 \%$ (zero-percent) BPHTB imposition policy is to ease the burden of lower middle-class communities and to promote the acceleration of land certification in DKI Jakarta. DKI Jakarta Provincial Government has well designed the direction of BPHTB Exemption Policy in DKI Jakarta Province by taking into account the needs of DKI Jakarta Provincial Government to maintain the revenue from BPHTB sector with a threshold for Tax Object Selling Value (NJOP) up to 2 billion Rupiahs exempted from BPHTB imposition, while supporting the Government program relating to accelerated land certification and improving the investment in land sector. BPHTB Exemption Policy up to 2 billion Rupiahs is expected to provide ease for the DKI Jakarta Residents especially to have residential settlement with burden of BPHTB payment obligation which has been maximized due to factor of relatively high selling price of land and Building in DKI Jakarta Province.

The cost from the implementation of 0\% (zero-percent) BPHTB imposition policy would be the number of DKI Jakarta Residents using the loopholes in the Local Regulation on BPHTB by not reporting the real value of the sale transaction when applying for zero-percent BPHTB imposition. The taxpayer tends to understate the transaction value to enjoy the policy (BPHTB payable to zero). This action is a violation of tax legislations by using the loophole in the Law tax or commonly called tax avoidance (tax avoidance).

Recommendation or policy direction toward the future recommended in this research is that DKI Jakarta Provincial Government needs to involve all stakeholders that the policy taken is effectively and efficiently targeted and aligned with the need of the communities, hence policy can be designed by considering all aspects, in term of benefit gained, possible impact, constraints and et cetera, and the policy taken will be continuing and not temporary. DKI Jakarta Government also needs to review the Tax Object Selling Value (NJOP) up to 2 billion as the basis for exemption. The policy taken by determining the basis not comprehensively studied may cause the primary goal to help lower middle-class communities to end in failure. Local Revenue Agency as the tax authority in charge of local tax in DKI Jakarta needs to perform complete update of the Tax Object Information System and Management (SISMIOP) data, either by means of field survey or system improvement. 


\section{REFERENCES}

Badan Pusat Statistik Provinsi DKI Jakarta. (2019). Sertifikasi Pertanahan DKI Jakarta. Download at www.bps.go.id

Banuaji, A. (2016). Analisis Cost and Benefit Kebijakan Pembebasan Pengenaan Pajak Bumi dan Bangunan Atas Rumah, Rusunawa Dan Rusunami Dengan Nilai Jual Objek Pajak Sampai Dengan Satu Miliar Rupiah Di Provinsi DKI Jakarta. Jakarta: Universitas Indonesia.

Cresswell, J.W. (2014). Research Design Qualitative, Quantitative, and Mixed Methods Approach - 4th Edition. London: SAGE Publications Ltd.

Dye, Thomas R. (2013). Understanding Public Policy (14 ${ }^{\text {th }}$ ed.). New Jersey: Pearson Education Inc.

Dunn, William N. (2018). Public Policy Analysis an Integrated Approach. New York: Routledge.

Falah, Fathiza Astri. (2012). Analisis Implementasi Kebijakan Pemberian Pengurangan, Keringanan dan Pembebasan Bea Perolehan, Hak atas dan Bangunan di DKI Jakarta. Jakarta: Universitas Indonesia

Faulk, Dagney. (2006). The Effects of Business Property Tax Incentives. Boston: Presented at the 99th Annual Conference on Taxation, National Tax Association

Febrian, A. (2017). Analisis Implementasi Kebijakan Pembebasan Bea Perolehan Hak Atas Tanah Dan Bangunan Di Provinsi DKI Jakarta. Jakarta: Universitas Indonesia.

Jibao dan Prichard (2015). The Political Economy of Poperti tax in Africa : Explaining Reform Outcomes in Sierra Leone. African Affairs, 114/456: 404-431

Kementerian Dalam Negeri. (2019). APBD DKI Jakarta. Download at www.kemendagri.go.id Koeswara. (1995). Motivasi, Teori dan Penelitiannya. Bandung: Penerbit Angkasa.

Kusumanegara, S. (2010). Model dan Aktor dalam Proses Kebijakan Publik. Yogyakarta: Gava Media. Mardiasmo (2011). Perpajakan Edisi Revisi 2011. Yogyakarta: Penerbit Andi.

Mark S. Rosentraub et all. (2010). Residential Property Tax Abatements and Rebuilding in Cleveland, Ohio. Sage Publication, Inc, 42(2): 104-117

Nurmantu, Safri. (2005). Pengantar Perpajakan edisi 3. Jakarta: Granit.

Nurul, Aisyah Rachmawati \& Rizka Ramayanti. (2016). Manfaat Pemberian Insentif Pajak Penghasilan Dalam Kepatuhan Wajib Pajak UMKM. Jurnal Akuntansi, 4(2): 176-185.

Ortax. (2017). Pembebasan BPHTB. Download at https://www.ortax.com

Pamungkas, D. D. (2019). Kebijakan Sanksi Administrasi BPHTB Untuk Pemberian Hak Baru Atas Tanah Di Provinsi DKI Jakarta Dalam Perspektif collaborative governance. Jurnal Manajemen Pelayanan Publik, 2(1), 34. https://doi.org/10.24198/jmpp.v2i1.21794

Provinsi Daerah Khusus Ibukota Jakarta, Peraturan Daerah Nomor 6 Tahun 2010 tentang Ketentuan Umum Pajak Daerah (Lembaran Daerah Provinsi Daerah Khusus Ibukota Jakarta Tahun 2010 Nomor 6, Tambahan Lembaran Daerah Provinsi Daerah Khusus Ibukota Jakarta Nomor 3);

Provinsi Daerah Khusus Ibukota Jakarta, Peraturan Daerah Nomor 18 Tahun 2011 tentang Bea Perolehan Hak Atas Tanah Dan Bangunan (Lembaran Daerah Provinsi Daerah Khusus Ibukota Jakarta Tahun 2010 Nomor 18, Tambahan Lembaran Daerah Provinsi Daerah Khusus Ibukota Jakarta Nomor 15);

Provinsi Daerah Khusus Ibukota Jakarta, Peraturan Gubernur Nomor 103 Tahun 2011 tentang Pemberian Pengurangan, Keringanan Dan Pembebasan Bea Perolehan Hak Atas Tanah Dan Bangunan (BPHTB) (Berita Daerah Provinsi Daerah Khusus Ibukota Jakarta Tahun 2011 Nomor 105)

Provinsi Daerah Khusus Ibukota Jakarta, Peraturan Gubernur Nomor 193 Tahun 2016 tentang Pembebasan 
100\% (Seratus Persen) Atas Bea Perolehan Hak Atas Tanah Dan Bangunan Karena Jual Beli Atau Pemberian Hak Baru Pertama Kali Dan/Atau Pengenaan Sebesar 0\% (Nol Persen) Bea Perolehan Hak Atas Tanah Dan Bangunan Karena Peristiwa Waris Atau Hibah Wasiat Dengan Nilai Jual Objek Pajak Sampai Dengan Dengan Rp2.000.000.000,00 (Dua Miliar Rupiah) (Berita Daerah Provinsi Daerah Khusus Ibukota Jakarta Tahun 2017 Nomor 71034)

Provinsi Daerah Khusus Ibukota Jakarta, Peraturan Gubernur Nomor 126 Tahun 2017 tentang Pengenaan 0\% (Nol Persen) Atas Bea Perolehan Hak Atas Tanah Dan Bangunan Terhadap Perolehan Hak Pertama Kali Dengan Nilai Perolehan Objek Pajak Sampai Dengan Rp2.000.000.000,00 (Dua Miliar Rupiah) (Berita Daerah Provinsi Daerah Khusus Ibukota Jakarta Tahun 2017 Nomor 71034)

Republik Indonesia, Undang-Undang Nomor 33 Tahun 2004 tentang Perimbangan Keuangan Antara Pemerintah Pemerintah Pusat dan Pemerintah Daerah (Lembaran Negara Republik Indonesia Tahun 2004 Nomor 126, Tambahan Lembaran Negara Republik Indonesia Nomor 4438);

Republik Indonesia, Undang-Undang Nomor 28 Tahun 2009 tentang Pajak Daerah dan Retribusi Daerah (Lembaran Negara Republik Indonesia Tahun 2009 Nomor 130, Tambahan Lembaran Negara Republik Indonesia Nomor 5049);

Republik Indonesia, Undang-Undang Nomor 23 Tahun 2014 tentang Pemerintahan Daerah (Lembaran Negara republik Indonesia Tahun 2014 Nomor 244, Tambahan Lembaran Negara Republik Indonesia Nomor 5587);

Rumah Bandung. (2019). Sewa dan jual properti - Trovit. https://rumah.trovit.co.id/rumah-bandung Salomo, Roy. V. (2002). Keuangan Daerah di Indonesia. Jakarta: STIA LAN. Press

Suparmoko, M. (2006). Asas-asas IImu Keuangan Negara. Yogyakarta: Bagian Penerbitan Fakultas Ekonomi Universitas Gadjah Mada.

Suryanto. (2018). Analisis Potensi Bea Perolehan Hak Atas Tanah dan Bangunan Sebagai Salah Satu Pajak Daerah. Jurnal Manajemen Pelayanan Publik, 3(3): 273-281

Tempo. (2016). Pengurangan BPHTB. Download at www.tempo.com

Thurony, Victor. (1996). Tax Law Design \& Drafting. International Monetary Fund.

Winarno, B. (2007). Kebijakan Publik Teori dan Konsep. Yogyakarta: Media Pressindo. 